\title{
Preventing violence by intimate partners in adolescence: an integrative review*
}

\section{A prevenção da violência por parceiro(a) íntimo(a) na adolescência: uma revisão integrativa La prevención de la violencia por pareja íntima en la adolescencia: una revisión integradora}

\section{Rebeca Nunes Guedes de Oliveira ${ }^{1}$, Rafaela Gessner², Bianca de Cássia Alvarez Brancaglioni ${ }^{3}$, Rosa Maria Godoy Serpa} da Fonseca ${ }^{4}$, Emiko Yoshikawa Egry ${ }^{4}$

How to cite this article:

Oliveira RNG, Gessner R, Brancaglioni BCA, Fonseca RMGS, Egry EY. Preventing violence by intimate partners in adolescence: an integrative review. Rev Esc Enferm USP. 2016;50(1):134-43. DOI: http://dx.doi.org/10.1590/S0080-623420160000100018

\begin{abstract}
* Article extracted from the course "A Tipesc e o enfrentamento da violência doméstica na perspectiva de gênero e geração”, Departamento de Enfermagem em Saúde Coletiva, Programa de Pós-Graduação Interunidades de Doutoramento, Escola de Enfermagem/Escola de Enfermagem de Ribeirão Preto, Universidade de São Paulo, 2014.

${ }^{1}$ Universidade de São Paulo, Escola de Enfermagem, Programa de Pós-Doutorado, São Paulo, SP, Brazil.

${ }^{2}$ Universidade de São Paulo, Escola de Enfermagem, Escola de Enfermagem de Ribeirão Preto, Programa Interunidades de Doutoramento, São Paulo, SP, Brazil.

${ }^{3}$ Universidade de São Paulo, Escola de Enfermagem, Programa de Pós-Graduação em Enfermagem, São Paulo, SP, Brazil.

${ }^{4}$ Universidade de São Paulo, Escola de Enfermagem, Departamento de Enfermagem em Saúde Coletiva, São Paulo, SP, Brazil.
\end{abstract}

\begin{abstract}
Objective: To analyze the scientific literature on preventing intimate partner violence among adolescents in the field of health based on gender and generational categories. Method: This was an integrative review. We searched for articles using LILACS, PubMed/MEDLINE, and SciELO databases. Results: Thirty articles were selected. The results indicate that most studies assessed interventions conducted by programs for intimate partner violence prevention. These studies adopted quantitative methods, and most were in the area of nursing, psychology, and medicine. Furthermore, most research contexts involved schools, followed by households, a hospital, a health center, and an indigenous tribe. Conclusion: The analyses were not conducted from a gender - and generation-based perspective. Instead, the scientific literature was based on positivist research models, intimately connected to the classic public healthcare model and centered on a singular dimension.
\end{abstract}

\section{DESCRIPTORS}

Adolescent; Violence; Domestic Violence; Gender and Health; Review. 


\section{INTRODUCTION}

Only recently has gender-based violence been recognized as a health issue and introduced as an object of scientific study. Constructed since the 1980s in the context of the feminist fight to lend social visibility to and promote the political inclusion of this phenomenon, the body of knowledge on violence in the field of health has been increasing significantly. The issue has also been introduced into the scope of health policies in Brazil. Most studies on intimate partner violence investigate violence in conjugal relationships between adults. However, more recently, these studies have given rise to investigations focused on intimate violence among young adults, also known as dating violence ${ }^{(1)}$.

One of the first studies to investigate the theme of dating violence between young adults 15 to 19 years old on a national level was conducted between 2007 and 2010 in public and private schools in 10 Brazilian state capitals. The results revealed an $86.9 \%$ prevalence of victimization and $86.8 \%$ for perpetration of some form of aggression during relationships, with $76.6 \%$ of young men and women being both victims and offenders of various forms of aggression ${ }^{(2)}$. The study points to the need for adolescent dating violence prevention and intervention strategies, considering both the magnitude and the vulnerabilities determined by the experiences that mark this generation.

The first experiences of individuals with affectionate and sexual relations, which are determined by current social norms and the construction of boys' and girls' gender identity, are associated with significant vulnerability concerning victimization or the perpetration of violence. Furthermore, violence in adolescence seems to be significantly related to childhood victimization, conjugal violence in adulthood, and violence witnessed in the family and the community. Thus, the phenomenon is understood as a continuum, and in this sense, early intervention aimed at prevention has shown promising results ${ }^{(2)}$.

Intimate partner violence among adolescents has its own set of characteristics and is as serious as violence that occurs between adults in terms of prevalence, injuries, and psychological and social damages to the victim. Therefore, it requires specific methods of approach ${ }^{(1)}$.

However, the analysis of violence among adolescents cannot be reduced to chronologically and biologically based aspects of this social group. Adolescence must be considered beyond the dimension of age, with emphasis on aspects related to social inclusion and power relations established by gender inequalities, experienced and normalized in respect to this generation. In order to promote healthy and violence-free relationships, this perspective needs to be understood and taken into account.

In this context, gender and generational categories are fertile units of analysis that bring to light important polarities for analyzing social phenomena. Generation defines the place occupied by adolescence, in such a way that these subjects are part of society and the world and therefore must be connected to larger social structures ${ }^{(3)}$.
Studies that assess prevention programs for intimate partner violence at various life stages reveal that early approaches based on gender equality can be effective in preventing the development of violent behavior ${ }^{(4-5)}$. Studies on prevention strategies are still scarce in Latin America; most research is still produced in North American countries ${ }^{(1)}$.

Violence perpetrated by intimate partners in adolescence needs to be addressed by health researchers. The content that currently guides comprehension on intimate relations in the field reproduces hegemonic attitudes, nurturing a counterculture that fosters values of violence and gender inequality at different life strategies. In light of the gap in scientific knowledge about dating violence among adolescents, specifically in Latin America, and with the aim of developing strategies to overcome this scenario, we conducted an analysis of the scientific literature on prevention of intimate partner violence among adolescents in the field of health, taking into consideration gender and generational categories. To this end, we used national and international databases to search for state-of-the-art knowledge on the topic of preventing intimate partner violence among adolescents.

\section{METHOD}

This integrative review followed the recommended stages for this type of study, namely: (1) developing the research question; (2) searching the literature and defining study inclusion and exclusion criteria; (3) identifying information to be extracted and categorized from studies; (4) evaluating the data from included studies; (5) interpreting the results; and (6) presenting a review and summary of the results ${ }^{(6)}$.

The research question defined for the review was: Do studies on violence by intimate partners among adolescents take into account gender - and generation-based issues?

We conducted a literature search of articles published up to November 2014 through the Latin American and Caribbean Health Sciences Literature (LILACS), Scientific Electronic Library Online (SciELO), and PubMed/MEDLINE databases. In the PubMed database, the following Medical Subject Heading (MeSH) terms were selected: Violence AND Adolescent AND Courtship AND Prevention $\&$ control. In the SciELO and LILACS databases, we used Dating violence AND Prevention as keywords. (Different terms were needed to search in SciELO and LILACS because no results were produced when using the same terms as those used in PubMed. As these databases do not use $\mathrm{MeSH}$ terms and there were no equivalent terms in the Health Science Descriptors (DECS) database, other keywords were selected to generate a greater number of articles from SciELO and LILACS.) The search for the MeSH term "AND Gender identity" in addition to the MeSH terms described above and the keyword "AND Gender" resulted in no new studies. Searches were conducted with the same descriptors in English, Portuguese, and Spanish.

Studies were included if they met the following criteria: the study addressed violence by intimate partners among adolescents; it was derived from primary research; it was available in full text; and it was written in English, Portuguese, or Spanish. We excluded studies with flawed meth- 
odology and those that did not contain the composing elements of scientific methodology.

The data were collected in November 2014. After screening the aforementioned sources, we found 61 potential references. Inclusion and exclusion criteria were applied, and 30 studies were selected. Of these, 1, 4, and 25 articles came from LILACS, SciELO, and PubMed, respectively. The 30 studies were analyzed in full by at least two researchers, who evaluated the studies for answers to the research question, using a standardized data analysis instrument ${ }^{(7)}$. A database was constructed, and findings were organized and synthesized to include study sample, objective, object, methodology, summary of results, and conclusion, in addition to aspects related to the prevention of intimate partner violence among adolescents.

\section{RESULTS}

Our search through the Brazilian and international scientific literature on dating violence prevention among adolescents resulted in 30 scientific articles, which displayed a predominance of quantitative approaches $(n=23)$; five studies used qualitative approaches, and two adopted both. Most studies were produced in North America, with the United States representing 57\% ( $\mathrm{n}=17)$. The other studies were produced in Canada, Thailand, Spain, Australia, the United Kingdom, Sweden, Portugal, Brazil, Mexico, Chile, Colombia, and South Africa.

Regarding the field of knowledge, only one study was from the field of education, and the other studies were from the field of health, concentrated in the areas of nursing, psychology, and medicine. Most research contexts included schools $(n=21)$, followed by households $(n=2)$, universities $(n=2)$, a hospital ( $n=1)$, a health center $(n=1)$, a doctor's office $(n=1)$, an indigenous tribe $(n=1)$, and another location $(n=1)$.

In relation to period of publication, the first study was published in 1997 and the most recent one in 2013, the year in which most of the studies were published. Other years of publication were $1998,2000,2001,2008,2010$, and 2012. In Latin America, the first study was published in 2010. This fact confirms how recent and scarce the research into dating violence among adolescents is in this region. Seventeen studies evaluated interventions carried out by prevention programs for intimate partner violence among adolescents. Of these, 14 consisted of educational sessions conducted with adolescent groups in schools, two used other approaches developed in the school environment, and one was applied only at home. Among these studies, five investigated the Safe Dates Program, which conducts joint interventions in schools and the community. One of the studies in the school environment described an intervention process that adopted Boal's Theater of the Oppressed as a strategy to prevent intimate partner violence among adolescents.

Most articles were exploratory $(n=11)$, followed by randomized clinical trials $(\mathrm{n}=8)$ assessing prevention programs, and longitudinal $(n=5)$, quasi-experimental $(n=3)$ and other studies $(\mathrm{n}=3)$.

Adolescents were the subjects of most of the studies, both boys and girls $(n=25)$. Two also included families as research subjects. Four studies were conducted with young women or female adolescents, and one was restricted to boys.

Concerning data collection techniques, there was a prevalence of scales and questionnaires $(n=23)$. Four used interviews, and three employed other techniques, such as theater session observation, secondary data, focus groups, and triangulation.

In terms of instruments, the studies either developed their own or adapted preexisting instruments. The Conflict in Adolescent Dating Relationships Inventory (CADRI) was the most prevalent, either in isolation or together with other questionnaires. Some studies partially adapted the CADRI, according to their objectives. The Safe Dates Evaluation, Safe Dates Physical Violence Perpetration Scale, and Conflicts Tactics Scale were also adopted. The studies that included interviews used open - and closed-ended questions.

Most of the quantitative studies used statistical data analysis methods, while the qualitative ones primarily used content analysis followed by ATLAS Ti software $(n=3)$. The objects of study analyzed are presented in Chart 1.

Chart 1 - Articles that formed the selected sample from PubMed/MEDLINE, LILACS and SCIELO databases, published between 1997 and 2013 - São Paulo, Brazil, 2014.

\begin{tabular}{|l|c|c|l|l|}
\hline Title & $\begin{array}{c}\text { Year } \\
\text { Country }\end{array}$ & Design & \multicolumn{1}{|c|}{ Interventions } & Outcomes \\
\hline $\begin{array}{l}\text { 1) Efficacy of a dating violence } \\
\text { prevention program on attitudes } \\
\text { justifying aggression }\end{array}$ & $\begin{array}{c}1997 \\
\text { USA }\end{array}$ & $\begin{array}{c}\text { Quasi- } \\
\text { experimental }\end{array}$ & $\begin{array}{l}\text { Five-session prevention curriculum } \\
\text { in schools. Assessment with a } \\
\text { questionnaire applied before and two } \\
\text { weeks after intervention with both } \\
\text { male and female adolescents and } \\
\text { comparison with a control group. }\end{array}$ & $\begin{array}{l}\text { Only intervention participants } \\
\text { presented a reduction in attitudes } \\
\text { justifying aggression by intimate } \\
\text { partners. }\end{array}$ \\
\hline $\begin{array}{l}\text { 2) An evaluation of Safe Dates, } \\
\text { an adolescent dating violence } \\
\text { prevention program }\end{array}$ & $\begin{array}{c}\text { (9) } \\
\text { USA }\end{array}$ & $\begin{array}{l}\text { Randomized } \\
\text { clinical trial }\end{array}$ & $\begin{array}{l}\text { Safe Dates Program. Intervention- } \\
\text { based primary (in schools) and } \\
\text { secondary (in the community for } \\
\text { detected cases) prevention program. }\end{array}$ & $\begin{array}{l}\text { The Program demonstrated } \\
\text { changes in dating violence } \\
\text { norms, gender stereotyping, and } \\
\text { awareness of support services. }\end{array}$ \\
\hline $\begin{array}{l}\text { 3) The Safe Dates program: 1-year } \\
\text { follow-up results }{ }^{(10)} \text {. }\end{array}$ & $\begin{array}{l}2000 \\
\text { USA }\end{array}$ & $\begin{array}{l}\text { Longitudinal } \\
\text { N=1603 }\end{array}$ & $\begin{array}{l}\text { Evaluation of Safe Dates, a dating } \\
\text { violence prevention program. }\end{array}$ & $\begin{array}{l}\text { The intervention did not result in } \\
\text { reduced violent behavior. }\end{array}$ \\
\hline $\begin{array}{l}\text { 4) Gender differences in the } \\
\text { longitudinal predictors of adolescent } \\
\text { dating violence }{ }^{(11)} \text {. }\end{array}$ & $\begin{array}{l}2001 \\
\text { USA }\end{array}$ & $\begin{array}{l}\text { Longitudinal } \\
\text { N=1013 }\end{array}$ & None & $\begin{array}{l}\text { The habits of couples, risky } \\
\text { behavior, and demographics } \\
\text { were various predictors of } \\
\text { violence committed by girls and } \\
\text { acceptance of prescribed norms of } \\
\text { violence by boys. }\end{array}$ \\
\hline
\end{tabular}


...continuation

\begin{tabular}{|c|c|c|c|c|}
\hline Title & $\begin{array}{l}\text { Year } \\
\text { Country }\end{array}$ & Design & Interventions & Outcomes \\
\hline $\begin{array}{l}\text { 5) Violence in adolescents' romantic } \\
\text { relationships: findings from a survey } \\
\text { amongst school-going youth in a } \\
\text { South African community }{ }^{(12)} \text {. }\end{array}$ & $\begin{array}{l}2002 \\
\text { South } \\
\text { Africa }\end{array}$ & $\begin{array}{l}\text { Exploratory } \\
\mathrm{N}=928\end{array}$ & None & $\begin{array}{l}\text { Approximately half of the boys } \\
\text { and girls reported involvement in } \\
\text { violent relationships. }\end{array}$ \\
\hline $\begin{array}{l}\text { 6) Personal and social contextual } \\
\text { correlates of adolescent dating } \\
\text { violence }^{(13)} \text {. }\end{array}$ & $\begin{array}{l}2003 \\
\text { USA }\end{array}$ & $\begin{array}{l}\text { Randomized } \\
\text { controlled } \\
\text { clinical trial } \\
\mathrm{N}=444\end{array}$ & None & $\begin{array}{l}\text { Religious service attendance } \\
\text { and parental monitoring were } \\
\text { protective against dating violence. }\end{array}$ \\
\hline $\begin{array}{l}\text { 7) Assessing the long-term effects } \\
\text { of the Safe Dates Program and a } \\
\text { Booster in Preventing and Reducing } \\
\text { Adolescent Dating Violence } \\
\text { Victimization and Perpetration }{ }^{(4)} \text {. }\end{array}$ & $\begin{array}{l}2004 \\
\text { USA }\end{array}$ & $\begin{array}{l}\text { Longitudinal } \\
\mathrm{N}=1603\end{array}$ & $\begin{array}{l}\text { Evaluation of the dating violence } \\
\text { prevention program Safe Dates and } \\
\text { booster effects. }\end{array}$ & $\begin{array}{l}\text { The booster did not improve the } \\
\text { effectiveness of the Safe Dates } \\
\text { program. }\end{array}$ \\
\hline $\begin{array}{l}\text { 8) Assessing the effects of the dating } \\
\text { violence prevention program "Safe } \\
\text { Dates" using random coefficient } \\
\text { regression modeling }{ }^{(14)} \text {. }\end{array}$ & $\begin{array}{l}2005 \\
\text { USA }\end{array}$ & $\begin{array}{l}\text { Randomized } \\
\text { clinical trial } \\
\mathrm{N}=1566\end{array}$ & $\begin{array}{l}\text { Evaluation of the effects of the dating } \\
\text { violence prevention program Safe } \\
\text { Dates using Random Coefficient } \\
\text { Regression Modeling. }\end{array}$ & $\begin{array}{l}\text { Safe Dates prevention effects } \\
\text { were found, and the program } \\
\text { was equally effective for males } \\
\text { and females and for whites and } \\
\text { nonwhites. }\end{array}$ \\
\hline $\begin{array}{l}\text { 9) Recent and past intimate partner } \\
\text { abuse and HIV risk among young } \\
\text { women }^{(15)} \text {. }\end{array}$ & $\begin{array}{l}2008 \\
\text { USA }\end{array}$ & $\begin{array}{l}\text { Longitudinal } \\
\qquad N=2058\end{array}$ & None. & $\begin{array}{l}\text { The nonuse of condoms can } \\
\text { be related to the inability to } \\
\text { successfully negotiate with a } \\
\text { partner. }\end{array}$ \\
\hline $\begin{array}{l}\text { 10) "Do you want somebody treating } \\
\text { your sister like that?": qualitative } \\
\text { exploration of how African American } \\
\text { families discuss and promote healthy } \\
\text { teen dating relationships }{ }^{(16)} \text {. }\end{array}$ & $\begin{array}{l}2008 \\
\text { USA }\end{array}$ & $\begin{array}{l}\text { Descriptive } \\
\text { exploratory } \\
\mathrm{N}=125\end{array}$ & None. & $\begin{array}{l}\text { Intimate partner violence was } \\
\text { mentioned spontaneously by the } \\
\text { adolescents' mothers and fathers, } \\
\text { motivated by family experiences. }\end{array}$ \\
\hline $\begin{array}{l}\text { 11) The evolution of an evaluation: } \\
\text { a case study using the tribal } \\
\text { participatory research model }{ }^{(17)} \text {. }\end{array}$ & $\begin{array}{l}2008 \\
\text { USA }\end{array}$ & $\begin{array}{l}\text { Case study } \\
\mathrm{N} \text { not } \\
\text { informed }\end{array}$ & $\begin{array}{l}\text { Evaluation of an intimate partner } \\
\text { violence prevention program applied } \\
\text { in American Indian communities. }\end{array}$ & $\begin{array}{l}\text { Normalization of violence by } \\
\text { intimate partners. Beliefs that } \\
\text { psychological violence should be } \\
\text { tolerated. }\end{array}$ \\
\hline $\begin{array}{l}\text { 12) Thai female adolescents' } \\
\text { perceptions of dating violence }{ }^{(18)} \text {. }\end{array}$ & $\begin{array}{l}2009 \\
\text { Thailand }\end{array}$ & $\begin{array}{c}\text { Exploratory } \\
\mathrm{N}=24\end{array}$ & None. & $\begin{array}{l}\text { Contributed to the understanding } \\
\text { of violence by intimate partners. }\end{array}$ \\
\hline $\begin{array}{l}\text { 14) Adolescent girls' responses to } \\
\text { warning signs of abuse in romantic } \\
\text { relationships: implications for } \\
\text { youth-targeted relationship violence } \\
\text { prevention }^{(20)} \text {. }\end{array}$ & $\begin{array}{l}2009 \\
\text { Australia }\end{array}$ & $\begin{array}{l}\text { Exploratory } \\
\mathrm{N}=146\end{array}$ & None. & $\begin{array}{l}\text { Substantial proportions of girls in } \\
\text { relationships reported exposure } \\
\text { to the risk of intimate partner } \\
\text { violence. }\end{array}$ \\
\hline $\begin{array}{l}\text { 15) Nurturing healthy relationships } \\
\text { through a community-based } \\
\text { interactive theater program } \\
(21)\end{array}$ & $\begin{array}{l}2010 \\
\text { USA }\end{array}$ & $\begin{array}{l}\text { Experience } \\
\text { report }\end{array}$ & $\begin{array}{l}\text { Theater of the Oppressed, addressing } \\
\text { themes such as: healthy and } \\
\text { unhealthy relationships, bullying, } \\
\text { sexual harassment, and early signs of } \\
\text { violence, between intimate partners } \\
\text { in adolescence. }\end{array}$ & $\begin{array}{l}\text { Interactive theater fostered } \\
\text { learning of new knowledge about } \\
\text { bullying and sexual harassment. }\end{array}$ \\
\hline $\begin{array}{l}\text { 16) Physical and psychological } \\
\text { aggression in dating relationships of } \\
\text { Spanish adolescents: motives and } \\
\text { consequences }^{(22)} \text {. }\end{array}$ & $\begin{array}{l}2010 \\
\text { Spain }\end{array}$ & $\begin{array}{l}\text { Exploratory } \\
\text { and } \\
\text { descriptive } \\
N=567\end{array}$ & None. & $\begin{array}{l}\text { Indicated gender-based differences } \\
\text { in the perpetration of violence. }\end{array}$ \\
\hline $\begin{array}{l}\text { 17) "He messed me up": Swedish } \\
\text { adolescent girls' experiences of } \\
\text { gender-related partner violence and } \\
\text { its consequences over time }{ }^{(23)} \text {. }\end{array}$ & $\begin{array}{l}2010 \\
\text { Sweden }\end{array}$ & $\begin{array}{l}\text { Exploratory } \\
\text { and } \\
\text { descriptive } \\
\mathrm{N}=2\end{array}$ & None. & $\begin{array}{l}\text { Emphasized the impact and } \\
\text { consequences of intimate partner } \\
\text { violence in adolescence. }\end{array}$ \\
\hline $\begin{array}{l}\text { 18) "Yo quiero, yo puedo...prevenir } \\
\text { la violencia": Programa breve de } \\
\text { sensibilización sobre violencia en el } \\
\text { noviazgo }{ }^{(24)} \text {. }\end{array}$ & $\begin{array}{l}2010 \\
\text { Mexico }\end{array}$ & $\begin{array}{l}\text { Exploratory } \\
\text { and } \\
\text { descriptive } \\
\mathrm{N}=2250\end{array}$ & $\begin{array}{l}\text { Assessment of the "Yo quiero, yo } \\
\text { puedo... prevenir la violencia" } \\
\text { program to raise awareness and } \\
\text { increase information about the } \\
\text { impact of intimate partner violence. }\end{array}$ & $\begin{array}{l}\text { Both boy and girl adolescents } \\
\text { recognized violence in intimate } \\
\text { relationships and identified } \\
\text { healthy forms of expressing love. }\end{array}$ \\
\hline $\begin{array}{l}\text { 19) Risk and protective factors } \\
\text { distinguishing profiles of adolescent } \\
\text { peer and dating violence } \\
\text { perpetration }{ }^{(25)} \text {. }\end{array}$ & $\begin{array}{l}2011 \\
\text { USA }\end{array}$ & $\begin{array}{c}\text { Exploratory } \\
\text { and } \\
\text { descriptive } \\
\mathrm{N}=2907\end{array}$ & None. & $\begin{array}{l}\text { Boys reported more severe } \\
\text { violence than girls. }\end{array}$ \\
\hline $\begin{array}{l}\text { 20) Youth attitudes toward dating } \\
\text { violence in Thailand }{ }^{(26)} \text {. }\end{array}$ & $\begin{array}{l}2011 \\
\text { Thailand }\end{array}$ & $\begin{array}{c}\text { Exploratory } \\
N=1296\end{array}$ & None. & $\begin{array}{l}\text { Presented elements related to the } \\
\text { endorsement of violence. }\end{array}$ \\
\hline
\end{tabular}


...continuation

\begin{tabular}{|c|c|c|c|c|}
\hline Title & $\begin{array}{c}\text { Year } \\
\text { Country }\end{array}$ & Design & Interventions & Outcomes \\
\hline $\begin{array}{l}\text { 22) Exposición a violencia entre los } \\
\text { padres de adolescentes y adultos } \\
\text { jóvenes víctimas de alguna conducta } \\
\text { de maltrato en el noviazgo }{ }^{(28)} \text {. }\end{array}$ & $\begin{array}{c}2011 \\
\text { Colombia }\end{array}$ & $\begin{array}{l}\text { Exploratory } \\
\text { and } \\
\text { descriptive }\end{array}$ & None. & $\begin{array}{l}\text { There was a statistically significant } \\
\text { relationship between exposure } \\
\text { to parental violence and intimate } \\
\text { partner violence. }\end{array}$ \\
\hline $\begin{array}{l}\text { 23) Assessing the effects of Families } \\
\text { for Safe Dates, a family-based teen } \\
\text { dating abuse prevention program }{ }^{(29)} \text {. }\end{array}$ & $\begin{array}{l}2012 \\
\text { USA }\end{array}$ & $\begin{array}{l}\text { Randomized } \\
\text { clinical trial } \\
\mathrm{N}=324\end{array}$ & $\begin{array}{l}\text { Telephone assessment of the effects } \\
\text { of a family prevention program } \\
\text { against teen dating abuse. }\end{array}$ & $\begin{array}{l}\text { Effective in promoting changes in } \\
\text { the family context that favor the } \\
\text { discussion about violence. }\end{array}$ \\
\hline $\begin{array}{l}\text { 24) Past Victimizations and } \\
\text { Dating Violence Perpetration in } \\
\text { Adolescence: The Mediating Role of } \\
\text { Emotional Distress and Hostility }{ }^{(30)} \text {. }\end{array}$ & $\begin{array}{c}2012 \\
\text { Canada }\end{array}$ & $\begin{array}{l}\text { Cross- } \\
\text { sectional } \\
\mathrm{N}=1259\end{array}$ & None. & $\begin{array}{l}\text { Dating violence prevention and } \\
\text { intervention strategies must be } \\
\text { adapted according to gender. }\end{array}$ \\
\hline $\begin{array}{l}\text { 25) One-year follow-up of a coach- } \\
\text { delivered dating violence prevention } \\
\text { program: a cluster randomized } \\
\text { controlled trial }{ }^{(31)} \text {. }\end{array}$ & $\begin{array}{l}2013 \\
\text { USA }\end{array}$ & $\begin{array}{l}\text { Randomized } \\
\text { clinical trial } \\
\mathrm{N}=1513\end{array}$ & $\begin{array}{l}15 \text { min. sessions to apply assessment } \\
\text { questionnaire (pre - and post-test) } \\
\text { with male high school students. }\end{array}$ & $\begin{array}{l}\text { Promising program to reduce } \\
\text { the perpetration and tolerance of } \\
\text { intimate partner violence among } \\
\text { teens. }\end{array}$ \\
\hline $\begin{array}{l}\text { 26) Breaking up is hard to do: } \\
\text { how teens end violent dating } \\
\text { relationships }{ }^{(32)} \text {. }\end{array}$ & $\begin{array}{l}2013 \\
\text { USA }\end{array}$ & $\begin{array}{l}\text { Exploratory } \\
\text { and } \\
\text { descriptive } \\
\mathrm{N}=83\end{array}$ & None. & $\begin{array}{l}\text { Participants described six ways to } \\
\text { end violent relationships. }\end{array}$ \\
\hline $\begin{array}{l}\text { 27) Shifting Boundaries: an } \\
\text { experimental evaluation of a dating } \\
\text { violence prevention program in } \\
\text { middle schools }{ }^{(33)} \text {. }\end{array}$ & $\begin{array}{l}2013 \\
\text { USA }\end{array}$ & $\begin{array}{l}\text { Longitudinal } \\
\text { and } \\
\text { experimental } \\
\mathrm{n}=354\end{array}$ & $\begin{array}{l}\text { Interventions divided into three } \\
\text { groups: classroom, school facility, } \\
\text { and both environments. }\end{array}$ & $\begin{array}{l}\text { The interventions developed both } \\
\text { in the school environment and } \\
\text { in the classroom proved to be } \\
\text { effective. }\end{array}$ \\
\hline $\begin{array}{l}\text { 28) Expect Respect support groups: } \\
\text { preliminary evaluation of a dating } \\
\text { violence prevention program for at- } \\
\text { risk youth }\end{array}$ & $\begin{array}{l}2013 \\
\text { USA }\end{array}$ & $\begin{array}{l}\text { Noncontrolled } \\
\text { assessment } \\
\mathrm{N}=144\end{array}$ & $\begin{array}{l}\text { Assessment of Expect Respect } \\
\text { support groups for at risk youth for } \\
\text { dating violence. }\end{array}$ & $\begin{array}{l}\text { There was an increase in conflict- } \\
\text { resolution behaviors, but there } \\
\text { was no reduction in violence } \\
\text { perpetration or victimization. }\end{array}$ \\
\hline $\begin{array}{l}\text { 29) Prevenção à violência no namoro } \\
\text { e promoção de habilidades de vida } \\
\text { em adolescentes }^{(35)} \text {. }\end{array}$ & $\begin{array}{l}2013 \\
\text { Brazil }\end{array}$ & $\begin{array}{l}\begin{array}{c}\text { Quasi- } \\
\text { experimental } \\
\mathrm{N}=60\end{array}\end{array}$ & $\begin{array}{l}\text { Assessment of an intervention to } \\
\text { prevent dating violence based on the } \\
\text { promotion of life skills and sexual } \\
\text { and reproduction rights. }\end{array}$ & $\begin{array}{l}\text { There was a reduction of sexist, } \\
\text { homophobic, and violent beliefs } \\
\text { with regard to gender roles. }\end{array}$ \\
\hline $\begin{array}{l}\text { 30) Relacionamentos íntimos juvenis: } \\
\text { programa para a prevenção da } \\
\text { violência }^{(36)} \text {. }\end{array}$ & $\begin{array}{l}2013 \\
\text { Portugal }\end{array}$ & $\begin{array}{l}\begin{array}{c}\text { Quasi- } \\
\text { experimental } \\
\mathrm{N}=220\end{array}\end{array}$ & $\begin{array}{l}\text { Assessment of dating violence } \\
\text { prevention Program "The fourth R" } \\
\text { (adapted to Portugal). }\end{array}$ & $\begin{array}{l}\text { Validation as an intervention } \\
\text { model to reduce actions that } \\
\text { legitimize dating violence, } \\
\text { especially among teen boys. }\end{array}$ \\
\hline
\end{tabular}

\section{DISCUSSION}

Based on the analysis of the articles in full, we observed that a significant portion of the research was assessment studies about violence prevention programs. Another portion focused on exploring the phenomenon by identifying violent behavior and its repercussions on health, findings considered relevant by the authors to underpin the prevention of the phenomenon. Most studies also presented data on the magnitude of the problem among the investigated population.

The articles demonstrated that dating violence is a reality for both female and male adolescents in the countries in which the studies were carried out ${ }^{(4,9,12-13,18,20,22-23,30)}$. It is a phenomenon of great significance ${ }^{(4,9,12-13,18,20,22,30)}$, characterized by the perpetration and experience of various types of violence $e^{(9,12-13,20,22-24,26-27,30)}$, on the part of both boys and $\operatorname{girls}^{(4,11-13,32)}$. However, the studies showed gender-related differences regarding the types of violence experienced and perpetrated $^{(4,11-12,18-19,22,25)}$.

A study in Thailand ${ }^{(18)}$ that investigated the perception of 24 adolescent girls toward dating and intimate partner violence identified that $31 \%(n=7)$ had experienced aggressive behaviors perpetrated by their current partners, such as demanding sexual relations; being pushed, strangled, insulted, or manipulated; and having objects thrown at them. Among the participants, $81 \%(n=19)$ reported having experienced controlling behaviors, such as being told by their partner where they could go and what time to return home, being criticized for their clothes, being forbidden to have male friends, and being refused the option of deciding what the couple would do together.

A study carried out in Australia(20) showed that $60 \%$ $(n=74)$ of the girls reported having experienced jealousy and possessive behavior perpetrated by their partner. In Canada ${ }^{(30)}$, a study with 1,259 male and female adolescents revealed that $13.6 \%(n=171)$ of the adolescents reported having both experienced and perpetrated physical violence, of which $16.6 \%(n=125)$ were female and $9.0 \%$ $(\mathrm{n}=46)$ were male. Another study carried out in Spain ${ }^{(22)}$ with 567 male and female adolescents revealed that $96.3 \%$ $(\mathrm{n}=546)$ admitted perpetrating psychological violence in their intimate relationships, while $95.4 \%(n=541)$ reported victimization. The percentage of adolescents that reported perpetrating physical violence was $24.3 \%(n=138)$, of which $16.1 \%(n=38)$ were male and $30.2 \%(n=100)$ were female, and $21.7 \%(n=123)$ reported having experienced this type of violence, of which $26.3 \%(n=62)$ were male and $17.5 \%$ $(n=58)$ were female.

Although the studies adopted different methodologies, they reveal the magnitude of the phenomenon, corroborating the results of a study carried out in 10 Brazilian state capitals with 3,205 male and female adolescents ${ }^{(2)}$. The results indicated that $86.9 \%$ of the adolescents had already been victims of some type of violence, and $86.8 \%$ confirmed having committed some form of aggression during a rela- 
tionship. The report of experienced physical violence varied from $24.2 \%$ to $15.9 \%$ in the 10 state capital cities, whereas the perpretation of physical violence varied from $34.1 \%$ to $17.9 \%$. As for verbal violence, $85 \%$ of adolescents reported victimization and $85.3 \%$ perpetration. Therefore, the results showed how both male and female adolescents experience and perpetrate violent behavior, with various types of violence occurring frequently.

Using a theoretical and philosophical framework that seeks to interpret data critically based on gender categories $^{(37)}$, dating violence can be understood as a social and historically constructed phenomenon, also determined by gender issues. Despite the fact that it is central to the discussion about dating violence and even though the results of the different studies ${ }^{(4,11-12,18-19,22,25)}$ presented gender-related characteristics, this category was not a central point of analysis for most of the studies included in the review. With exception of one study conducted with Thai female adolescents about the naturalization of violence ${ }^{(18)}$, at the most, the other studies differentiated only some issues between boys and girls.

One North American study revealed significant differences in the establishment of dating violence among adolescents. Boys reported practicing more severe types of violence than girls. For girls, the results showed that social ties developed in school were associated with a reduced probability of perpetrating violence. Surprisingly, the same was not true for boys, as among them, social ties were associated with an increased probability of practicing violence in relationships with both male and female adolescents ${ }^{(25)}$.

Other results indicated gender differentiation in the occurrence of violence by intimate partners. One study identified that girls reported perpetrating verbal and psychological violence more often than boys ${ }^{(22)}$. This finding raised different questions, one of which was explored by the authors, that being whether this profile can be associated with the practice of feminine self-defense. According to their understanding, when physically abused, girls can end up resorting to verbally and psychologically violent behaviors to defend themselves ${ }^{(22)}$.

However, a gender-based analysis of this issue presented in the $\operatorname{article}^{(22)}$ leads to new insights. For example, we can question if girls actually do practice more psychological violence than boys or if they report this behavior more than boys due to gender-based aspects. The second issue regards the naturalization of verbal and psychological violence, considering the acceptance and sometimes encouragement given to many behaviors and forms of treatment that place women in inferior positions.

One study ${ }^{(18)}$ drew attention to the naturalization and acceptance of the phenomenon of violence. Even though it was conducted with Thai teenage girls, and therefore is susceptible to different cultural interpretations, the results of this study revealed important gender issues regarding the perception and impact of violence among youth. The results show that dating violence is a form of violence generalized and sustained by the patriarchy model, which confers different social positions to men and women and that, in the same way, labels women as part of different stigmatized groups. The distinction between good and bad girls is a constant, referred to by most of the interviewed adolescents ${ }^{(18)}$. Good girls are those who present socially valued qualities, such as good behavior, politeness, and virginity, i.e., girls who can be chosen for marriage. In turn, bad girls are those with whom men have only casual relationships.

This view is related to the stigma of sex before marriage, which is prohibited to women but socially accepted among men. This stigmatized concept that deliberately segregates and labels women was corroborated by another Thai study $^{(26)}$, whose results indicated the cultural influence of gender identity construction. The understanding that violent situations are unavoidable and even to be expected as part of romantic relationships leads to the naturalization of the phenomenon, subjugating women to male authority.

Intervention programs conducted in schools, and especially those aimed at families, proved to be efficient in preventing dating violence among adolescents ${ }^{(16,19)}$. However, it is worth noting that even the assessment of these measures can be affected by the experience of gender roles and norms in the field of sexuality. An example of this was demonstrated in a study with over 1,700 adolescents in London, in which half the group were submitted to an intervention. Only the boys submitted to the intervention reported increased use of condoms in sexual relations, a finding that challenges the generalized construction that girls supposedly have power of decision over their own bodies. In light of this, we can question if the girls who participated in the study did not in fact want to use condoms more often during sexual relations or if they did not have any decisionmaking power, thus being naturally subjugated to their partner's decision $^{(19)}$.

Only two of the analyzed studies ${ }^{(16,26)}$ came close to carrying out a gender-based analysis, albeit tangentially, by mentioning in the final considerations the need to incorporate the category when exploring the topic of dating violence. By assessing the phenomenon through the risk perspective and based on the assumption that it occurs in similar ways across different gender, social class, and ethnic groups, these studies can incur in the misleading and dangerous conclusion that prevention measures aimed at addressing the problem do not need to incorporate social determinants of violence.

Our analysis of the articles also revealed the role of the generational category in determining dating violence among adolescents. We observed that the subalternity of generation makes this group especially vulnerable to violence by intimate partners, as it blocks dialogue between adolescents and adults, an essential factor for its prevention and to help adolescents end violent relationships.

The generational category is also very important for understanding intimate partner violence among adolescents. It reveals processes of historical and social changes that have impacted the intimate relationships of adolescents, such as world wars, feminist movements, and the development of means of communication that favor the quick circulation of information ${ }^{(2)}$. 
We wish to highlight that the studies were produced under a positivist perspective and prioritized the analysis of risk factors over understanding determinants of the health-illness process. These determinants are understood as the vulnerabilities and potentials of each individual, which determine, among other things, the occurrence of violent processes among adolescents.

The articles analyzed in this review justify the importance and urgency of new and improved strategies for preventing violence by intimate partners among adolescents, especially in the school environment. The results showed that experiences with violent situations in adolescent relationships are associated with greater exposure to risk factors or behaviors, such as depression, sadness, and alcohol and drug abuse ${ }^{(19,25)}$.

A Swedish study conducted between 2005 and 2007 investigated the effects of intimate partner violence on the life of victimized adolescent girls. The results showed physical and emotional stress, which affected work and studies and led to fear of new relationships, due primarily to the view of their body as a crime scene, post-traumatic stress, and difficulties talking about the topic ${ }^{(23)}$.

Along these lines, a Canadian study ${ }^{(30)}$ demonstrated that girls who had been victims of sexual harassment showed a greater perpetration of violence against their partners. In turn, another study demonstrated the potential of prevention programs to reduce exposure to risk factors and behaviors. The results showed that the male adolescents who participated in the intervention program reported greater condom use in their sexual relations up to five years after intervention ${ }^{(19)}$.

Special mention goes to social relationships among adolescents, especially those developed in the school environment, and their effect on determining the occurrence of dating violence. The acceptance and naturalization of attitudes such as jealousy and excessive control, defamation, public humiliation, and possessiveness by adolescents was significantly associated with the determination and acceptance of violence ${ }^{(20,23)}$. However, one of the studies showed that these social relationships can also function as a form of prevention, as group attitudes of non-acceptance of violence were associated with lower chances of violence perpetration ${ }^{(25)}$.

Even though the studies chosen for this analysis were based primarily on a risk framework, this view can be overcome by adopting the concept of vulnerability, given that it precedes risk and takes into account the social insertion of groups in the determination of the phenomenon. The concept of vulnerability brings together the abstract elements associated and associable with the illness process and concrete and individual dimensions. Studies that adopt a vulnerability framework differ from those that assess risk, as they aim to achieve universality instead of wide-reaching reproducibility of phenomenology and inferences. Thus, the concept of vulnerability reveals potential illness, non-illness, and coping at the individual level ${ }^{(38)}$.

This view is essential so that we can think past prevention - a concept based on illness and risk - and adopt a view based on health promotion and gender equality. There- fore, in order to address the vulnerabilities associated with violence, a complex, multifaceted, and socially determined phenomenon, we must adopt a perspective that gives priority to the social determination of the health-illness process and goes beyond quantified approaches to risk.

Of all the studies analyzed, 17 assessed intervention programs carried out with adolescents with the purpose of preventing intimate partner violence $\mathrm{e}^{(4,8-11,14,17,19,21,24,27,29,31,33-36)}$.

Of these, the Coach Delivery program, conducted with young male athletes as part of the school curriculum, was considered promising, successfully bringing youth together and reducing violence by intimate partners. Its results showed the program's potential to promote attitudes that counter aggressive behaviors ${ }^{(31)}$.

Another study carried out an intervention with adolescents and their families and revealed a significant association between the condition of the intervention group and motivational factors for prevention. The follow-up with this group showed that the fathers, mothers, and legal guardians presented increased awareness of the gravity of intimate partner violence, displayed more effective responses for preventing such violence, and increased conditions to talk with their adolescent children about the topic. The program effectively promoted change within the family context, which favored continued discussions about violence. Thus, it proved to be a powerful intervention for reducing negative communication among fathers, mothers, and adolescents ${ }^{(29)}$.

The Expect Respect program resulted in increased reports of healthy behaviors and conflict resolution. However, in general, such skills did not result in less violence perpetration or victimization. Participants who displayed perpetration behaviors on the pretest and who underwent the most number of sessions were more prone to report perpetration on the post-test, displaying heightened recognition of their violent behavior ${ }^{(34)}$.

Five articles investigated the Safe Dates program, which is based on curricular and community activities to prevent and reduce intimate partner violence in adolescence. The school activities involved producing a play, curricular sessions, and a poster contest. In the community, the program developed services for adolescents in abusive relationships, such as support groups, material for parents, and a hotline for crisis situations ${ }^{(4,8-9,14)}$.

The results of the Safe Dates intervention were reflected primarily through changes in intimate partner violence norms and gender roles. Furthermore, participants were less tolerant of violence, presented higher awareness of the negative consequences of violent relationships, and were more aware of the services available for victims and perpetrators ${ }^{(4,8-9,14)}$.

In contrast, the findings of a 2014 North American systematic review ${ }^{(39)}$ of the effectiveness of prevention programs directed at sexual violence between intimate partners revealed gaps in terms of the assessment of the results, given the challenges inherent to analyzing changes in behavior over a limited timeframe. The authors pointed to inconsistencies due to the impossibility of quantifying the measurement of violent attitudes and behaviors, the use of different assessment instruments that hinder the comparison of re- 
sults, and the challenge of long-term assessments presented by most of the studies ${ }^{(39)}$.

Another study assessed a program based on the Theater of the Oppressed technique, which proved to be a powerful experience that fostered the acquisition of new knowledge about bullying and sexual harassment. Based on their own experience, participating adolescents stated that their behavior and that of their peers could be changed with the new information learned during the process ${ }^{(21)}$.

Special mention goes to the Yo quiero, yo puedo...prevenir la violencia ${ }^{(24)}$ program developed in Mexico, whose methodology included the use of a gender-based theoretical framework to address themes such as sexuality, gender, and their relation to violence in one of the eight proposed conferences. The authors started the discussion by addressing gender-based issues and emphasized that historically constructed power differences between men and women legitimize the violence process also among adolescents. In light of this, they argue in favor of prevention programs that encourage gender equity among more youth. The results showed that after participating in the program, boys showed a $20 \%$ increase in their capacity to recognize intimate partner violence, demonstrating that such violence has been naturalized, especially among the male population.

Another study developed in Portugal evaluated the impact of the the Fourth $\mathrm{R}$ program ${ }^{(36)}$ for preventing violence by intimate partners and corroborated the findings of the $Y_{0}$ quiero, yo puedo...prevenir la violencia ${ }^{(24)}$ program. The results showed significant changes, with lower levels of violence legitimization and increased positive conflict-resolution skills among the boys who participated in the intervention.

Similarly, the program Construyendo una Relación de Pareja Saludable(27) also inserted the gender category into its methodological construction, addressing themes such as power differences in gender relationships, the emergence of gender stereotyping, and the practice of violence. The assessment of this program's implementation confirmed that participants presented higher recognition of intimate partner violence, which included subtle forms of violence and their different manifestations. The authors believe that the program's success was related to the diversity of pedagogical strategies employed, such as games. The participants mentioned this strategy as one of the modalities that most favored significant learning due to its interactive nature.

A study carried out in a Brazilian high school ${ }^{(35)} \mathrm{em}-$ phasized that one of the main challenges for conducting prevention interventions among adolescents is their motivation to participate in the program. In this sense, the authors considered it necessary to include the assessment of adolescents' interests as a tool to design the intervention, thus including priorities listed by participants themselves. The results pointed to interactions that elicited greater responsiveness from adolescents, favoring adherence.

Most of the studies were based on curricular interventions and, in general, the authors recommended that interventions be implemented as early as possible, as attitudes and behaviors related to the experience of sexuality and gender roles are formed before the first sexual experience, and gender roles are molded long before the first experience with affective relationships. Thus, the studies ${ }^{(14,22,26,29,33)}$ suggested formulating strategies that involve families, peers, and the context in which adolescents are inserted. This context is deeply related to the formation and acceptance of attitudes and behaviors in intimate relationships and conflict management that involves relationships and attitudes ${ }^{(26)}$. Furthermore, the studies pointed to the need to emphasize primary prevention, directed at reducing the incidence of intimate partner violence before it occurs. The studies also showed the need for intervention strategies in the field of health services.

The programs analyzed in this review used different strategies, ranging from lectures to dramatizations, educational pamphlets, games, and theater. However, only a minority emphasized the social context of adolescents and considered the important role of culture and peers in the formation and maintenance of values that permeate intimate relationships. Such knowledge could serve as the basis for the creation of models that associate dating violence in adolescence with conflictual conjugal relationships in families, for example, in order to underpin increasingly more powerful interventions that include the family and social context.

In general, the studies highlighted the problem of dating violence in adolescence and its short - and long-term consequences. Their results pointed to the absence of specific public policies to prevent and address the phenomenon during this life phase and the importance of early prevention strategies in light of the magnitude of its consequences. The scientific literature about violence by intimate partners in adolescence broadly discussed the need for including the issue as a work objective in the routine of healthcare services, in addition to developing an ongoing assessment of prevention programs that involve the schools, family, and social context of adolescents.

\section{CONCLUSION}

In general, the studies that assessed or discussed prevention of dating violence among adolescents did not analyze the phenomenon based on gender and generational categories. Among other aspects, one aim of this review was to analyze to what extent the studies presented the possibility of relating these social categories with dating violence in adolescence within the context of the experience of sexuality. We based our discussion on the assumption that this type of violence takes on significant importance in this life phase and is deeply associated with the construction of gender identity, sexuality, and the determination of violence, an aspect that was not identified in the analysis of most of the studies.

Most of the studies that assessed the prevention of dating violence were focused on the recognition of and raising awareness about violence, in addition to conflict-resolution skills and gender stereotyping. These aspects were recognized as strategies that provide adolescents with the tools to manage problematic relationships before interpersonal vulnerability habits are established. However, the studies failed to address issues that surpass the singular dimension 
of attitudes and behaviors and that expand the discussion to include the social context of culture, peers, media, and the social insertion of adolescents.

The analyzed studies lacked any discussion about social structure, in terms of prevention and coping policies and the incorporation of adolescents into the political and ideological structure as a social group. These aspects reveal a scientific production based on positivist research models, intimately connected to the classic public healthcare model and centered on a singular dimension.

\section{RESUMO}

Objetivo: Analisar a produção científica sobre a prevenção da violência por parceiro(a) íntimo(a) entre adolescentes no campo da saúde, considerando as categorias de gênero e geração. Método: Revisão integrativa, cuja busca foi realizada nas bases de dados LILACS, PubMed/MEDLINE e SciELO. Resultados: Foram selecionados 30 artigos. Os resultados indicam que a maior parte dos estudos tratava da avaliação de intervenções por programas de prevenção da violência por parceiro(a) íntimo(a). O método predominante foi o quantitativo, no que concerne à área de conhecimento os estudos concentram-se nas áreas de enfermagem, psicologia e medicina. A maioria dos cenários dos estudos foi constituída por escolas, seguidos de domicílio, hospital, centro de saúde e tribo indígena. Conclusão: Constata-se que a análise do fenômeno não foi realizada a partir de uma perspectiva de gênero e geração, estando a produção científica pautada nos moldes positivistas de pesquisa, que se aproximam da lógica da saúde pública clássica e centrada na dimensão singular.

\section{DESCRITORES}

Adolescente; Violência; Violência Doméstica; Gênero e Saúde; Revisão.

\section{RESUMEN}

Objetivo: Analizar la producción científica acerca de la prevención de la violencia por pareja íntima entre adolescentes en el campo de la salud, considerando las categorías de género y generación. Método: Revisión integradora, cuya búsqueda se llevó a cabo en las bases de datos LILACS, PubMed/MEDLINE y SciELO. Resultados: Fueron seleccionados 30 artículos. Los resultados señalan que la mayor parte de los estudios trataba de la evaluación de intervenciones por programas de prevención de la violencia por pareja íntima. El método predominante fue el cuantitativo; en lo que se refiere al área de conocimiento los estudios se concentran en las áreas de enfermería, psicología y medicina. La mayoría de los escenarios de los estudios estuvo constituida de escuelas, seguidos de domicilio, hospital, centro de salud y tribu indígena. Conclusión: Se constata que el análisis del fenómeno no fue realizado desde una perspectiva de género y generación, estando la producción científica pautada en los modelos positivistas de investigación, que se acercan a la lógica de la salud pública clásica y centrada en la dimensión singular.

\section{DESCRIPTORES}

Adolescente; Violencia; Violencia Doméstica; Género y Salud; Revisión.

\section{REFERENCES}

1. Organização Mundial da Saúde. Prevenção da violência sexual e da violência pelo parceiro íntimo contra a mulher: ação e produção de evidência [Internet]. Genebra: OMS; 2012 [citado 2014 dez. 05]. Disponível em: http://apps.who.int/iris/ bitstream/10665/44350/3/9789275716359_por.pdf

2. Minayo MCS. Amor e violência: um paradoxo das relações de namoro e do "ficar" entre jovens brasileiros. Rio de Janeiro: Fiocruz; 2011.

3. Egry EY, Fonseca RMGS, Oliveira MAC. Ciência, Saúde Coletiva e Enfermagem: destacando as categorias gênero e geração na episteme da práxis. Rev Bras Enferm. 2013;66(n.esp):119-33.

4. Foshee VA, Bauman KE, Ennett ST, Linder GF, Benefield T, Suchindran C. Assessing the long-term effects of the Safe Dates program and a booster in preventing and reducing adolescent dating violence victimization and perpetration. Am J Public Health. 2004;94(4):619-24.

5. Foshee VA, Karriker-Jaffe KJ, Reyes HLM, Ennett ST, Suchindran C, Bauman KE, et al. What accounts for demographic differences in trajectories of adolescent dating violence? An examination of intrapersonal and contextual mediators. J Adolesc Health. 2008;42(6):596-604.

6. Mendes KDS, Silveira RCCP, Galvão CM. Revisão integrativa: método de pesquisa para a incorporação de evidências na saúde e na enfermagem. Texto Contexto Enferm. 2008;17(4):758-64.

7. Knafl K, Sandelowski M. "Mixed methods synthesis of research on childhood chronic conditions and family" [Internet]. Chapel Hill: UNC/ School of Nursing; 2011 [cited 2015 Mar 22]. Available from: http://familysynthesis.unc.edu/etc/Final_Proposal.pdf

8. Avery-Leaf S, Cascardi M, O'Leary KD, Cano A. Efficacy of a dating violence prevention program on attitudes justifying aggression. J Adolesc Health. 1997;21(1):11-7.

9. Foshee VA, Bauman KE, Arriaga XB, Helms RW, Koch GG, Linder GF. An evaluation of Safe Dates, an adolescent dating violence prevention program. Am J Public Health. 1998;88(1):45-50.

10. Foshee VA, Bauman KE, Greene WF, Koch GG, Linder GF, MacDougall JE. The Safe Date program: 1-year follow-up results. Am J Public Health. 2000;90(10):1619-22.

11. Foshee VA, Linder F, MacDougall JE, Bangdiwala S. Gender differences in the longitudinal predictors of adolescent dating violence. Prev Med. 2001;32(2):128-41.

12. Swart LA, Seedat M, Stevens G, Ricardo I. Violence in adolescents' romantic relationships: findings from a survey amongst school-going youth in a South African community. J Adolescence. 2002;25(4):385-95.

13. Howard D, Qiu Y, Boekeloo B. Personal and social contextual correlates of adolescent dating violence. J Adolesc Health. 2003;33(1):9-17. 
14. Foshee VA, Bauman KE, Ennett ST, Suchindran C, Benefield T, Linder GF. Assessing the effects of the dating violence prevention program "safe dates" using random coefficient regression modeling. Prev Sci. 2005;6(3):245-58.

15. Teitelman AM, Ratcliffe SJ, Dichter ME, Sullivan CM. Recent and past intimate partner abuse and HIV risk among young women. J Obstet Gynecol Neonatal Nurs. 2008;37(2):219-27.

16. Akers AY, Yonas M, Burke J, Chang JC. "Do you want somebody treating your sister like that?" Qualitative exploration of how African American families discuss and promote healthy teen dating relationships. J Interpers Violence. 2011;26(11):2165-85.

17. Richmond LS, Peterson DJ, Betts SC. The evolution of an evaluation: a case study using the tribal participatory research model. Health Promot Pract. 2008;9(4):368-77.

18. Thongpriwan V, McElmurry BJ. Thai female adolescents' perceptions of dating violence. Health Care Women Int. 2009;30(10):871-91.

19. Wolfe DA, Crooks C, Jaffe P, Chiodo D, Hughes R, Ellis W, et al. A school-based program to prevent adolescent dating violence: a cluster randomized trial. Arch Pediatr Adolesc Med. 2009;163(8):692-9.

20. Murphy KA, Smith DI. Adolescent girls' responses to warning signs of abuse in romantic relationships: implications for youth-targeted relationship violence prevention. J Interpers Violence. 2010;25(4):626-47.

21. Fredland NM. Nurturing healthy relationships through a community-based interactive theater program. J Community Health Nurs. 2010;27(2):107-18.

22. Fernández-Fuertes AA, Fuertes A. Physical and psychological aggression in dating relationships of Spanish adolescents: motives and consequences. Child Abuse Negl. 2010;34(3):183-91.

23. Wiklund M, Malmgren-Olsson EB, Bengs C, Ohman A. "He messed me up": Swedish adolescent girls' experiences of gender-related partner violence and its consequences over time. Violence Against Women. 2010;16(2):207-32.

24. Pick S, Leenen I, Givaudan M, Prado A. "Yo quiero, yo puedo... prevenir la violencia": programa breve de sensibilización sobre violencia en el noviazgo. Salud Mental. 2010;33(2): 153-60.

25. Foshee VA, Reyes HL, Ennett ST, Suchindran C, Mathias JP, Karriker-Jaffe KJ, et al. Risk and protective factors distinguishing profiles of adolescent peer and dating violence perpetration. Adolesc Health. 2011;48(4):344-50.

26. Pradubmook-Sherer P. Youth attitudes toward dating violence in Thailand. Int J Offender Ther Comp Criminol. 2011;55(2):182-206.

27. Póo AM, Vizcarra MB. Diseño, implementación y evaluación de un Programa de Prevención de la Violencia en el Noviazgo.Ter Psicol. 2011;29(2):213-23.

28. Rey-Anacona CA. Exposición a violencia entre los padres de adolescentes y adultos jóvenes víctimas de alguna conducta de maltrato en el noviazgo. Diversitas. 2011;7(2):253-64.

29. Foshee VA, Reyes HLM, Ennett ST, Cance JD, Bauman KE, Bowling JM. Assessing the effects of Families for Safe Dates, a family-based teen dating abuse prevention program. J Adolesc Health. 2012;51(4):349-56.

30. Boinvin S, Lavoie F, Hébert M, Gagné M. Past victimizations and dating violence perpetration in adolescence: the mediating role of emotional distress and hostility. J Interpers Violence. 2012;27(4):662-84.

31. Miller E, Tancredi DJ, McCauley HL, Decker MR, Virata MC, Anderson HA, et al. One-year follow-up of a coach-delivered dating violence prevention program: a cluster randomized controlled trial. Am J Prev Med. 2013;45(1):108-12.

32. Martsolf DS, Draucker CB, Brandau M. Breaking up is hard to do: how teens end violent dating relationships. J Am Psychiatr Nurses Assoc. 2013;19(2):71-7.

33. Taylor BG, Stein ND, Mumford EA, Woods D. Shifting Boundaries: an experimental evaluation of a dating violence prevention program in middle schools. Prev Sci. 2013;14(1):64-76.

34. Ball B, Tharp AT, Noonan RK, Valle LA, Hamburger ME, Rosenbluth B. Expect respect support groups: preliminary evaluation of a dating violence prevention program for at-risk youth. Violence Against Women. 2012;18(7):746-62.

35. Murta SG, Santos BRP, Nobre LA, Araújo IF, Miranda AAV, Rodrigues IO, et al. Prevenção à violência no namoro e promoção de habilidade de vida em adolescentes. Psicol USP. 2013;24(2):263-88.

36. Saavedra R, Martins C, Machado C. Relacionamentos íntimos juvenis: programa para a prevenção da violência. Psicologia. 2013;27(1):115-32.

37. Fonseca RMGS. Gênero e saúde da mulher: uma releitura do processo saúde doença das mulheres. In: Fernandes RAQ, Narchi NZ, organizadoras. Enfermagem e saúde da mulher. São Paulo: Manole; 2012. p. 30-68.

38. Munoz Sanchez Al, Bertolozzi MR. Pode o conceito de vulnerabilidade apoiar a construção do conhecimento em Saúde Coletiva? Ciênc Saúde Coletiva. 2007;12(2):319-24.

39. Lundgren R, Amin A. Addressing intimate partner violence and sexual violence among adolescents: emerging evidence of effectiveness. J Adolesc Health. 2015;56(1 Suppl):S42-50. 